\title{
WORDS AND WALLS, TEXTS AND TEXTILES: A CONVERSATION
}

MARIAM MOTAMEDI FRASER AND FARNIYAZ ZAKER

\begin{abstract}
The authors explore how the multi-media artist Farniyaz Zaker uses words to establish connections between different kinds of materials in her work, and how her work makes words material. Zaker's conception of dress as 'microcosmic dwelling places' enables the authors to think about veiling practices, Islams and gender not only in relation to the familiar domains of state, piety, subjectivity, consumption, capitalism, public and private (for instance), but also with regards to some less selfevidently relevant contexts. Light, architecture and cinema, as well as walls, windows, curtains, coffins, tents and screens, are among them. It is by way of these multiple refractions that the authors are able to return to those debates that conceive of Islamic veiling in terms of embodied, material practices and to support and develop further reasons for an understanding of that most exceptionally charged piece of material, the veil, as more than a sign of ...
\end{abstract}

\section{KEY WORDS}

Dress, architecture, veiling, words, signs, materiality, Islamic 


\section{WORDS AND WALLS, TEXTS AND TEXTILES: A CONVERSATION}

MARIAM MOTAMEDI FRASER AND FARNIYAZ ZAKER

The following conversation is based on a discussion event that was held at Goldsmiths, University of London, in conjunction with the launch of Farniyaz Zaker's exhibition a black dress, a red dress (2013). It is an exploration of the authors' shared interest in the material, visceral dimension of words, and of words as more than signs. (Or, to put that differently, of words as not only pointers to intentions and meanings that lie elsewhere). In this paper, we explore how Farniyaz uses words to establish connections between different kinds of materials in her work - the materials of dress in particular - , and how her work makes words material. Although the paper is not about veiling practices, Islams and gender per se, the nature of the discussion nevertheless raises issues that are relevant to them. Indeed our intentionally oblique approach enables us to think about gender and dress not only in relation, for instance, to the familiar and important domains of state, piety, subjectivity, consumption and capitalism, public and private, liberal politics and 'the powers of freedom' (Amir-Moazami et al., 2011), but also with regards to some less self-evidently relevant contexts. Light, architecture, and cinema are among them. So too are walls, windows, curtains, coffins, tents and screens. All of these connections are generated by Farniyaz's understanding of dress as 'microcosmic dwelling places.' It is by way of these multiple refractions that we return, enriched (we hope), to those debates that conceive of Islamic veiling in terms of embodied, material practices (Mahmood, 2005). Through our discussion of Farniyaz's work and the role of words within it, we support and develop further reasons for an understanding of that most exceptionally charged piece of material, the veil, as more than $a$ sign of ....

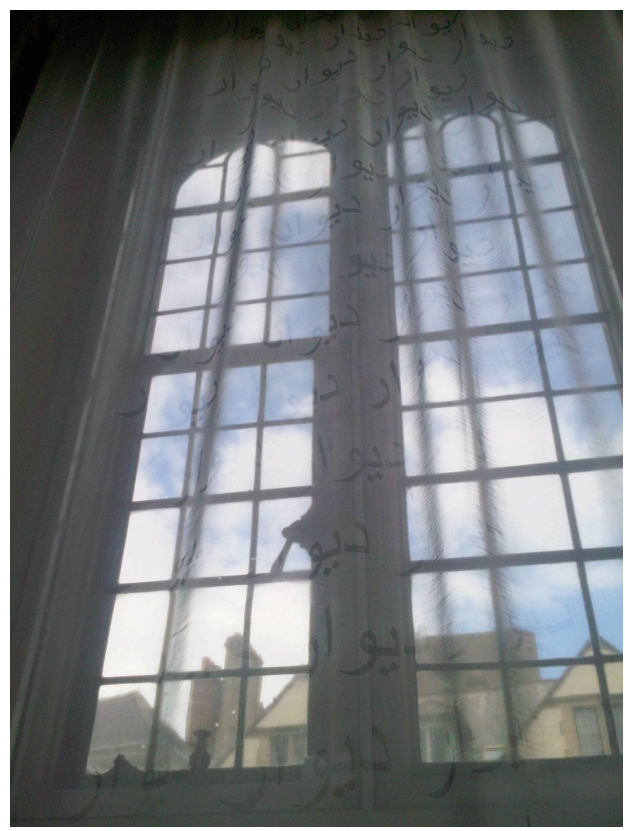


Fig. 1. Pardeh, 2011

Old Masters Room, The Ruskin School of Drawing and Fine Arts, Oxford, UK

MMF: I would like to start by asking you about two of your pieces, both of which use the word 'pardeh' - برده - which means curtain in Farsi. The first piece is entitled Pardeh (2011). It is composed of an almost transparent curtain, on which the word divar - دىوار - which means 'wall' in Farsi - is printed (Figure 1).

The second piece is called Pause in Movement (2012). Here, the word pardeh is printed, in a repeating pattern, on a dress (Figure 2). Could you say something about these two pieces please, and their connections?

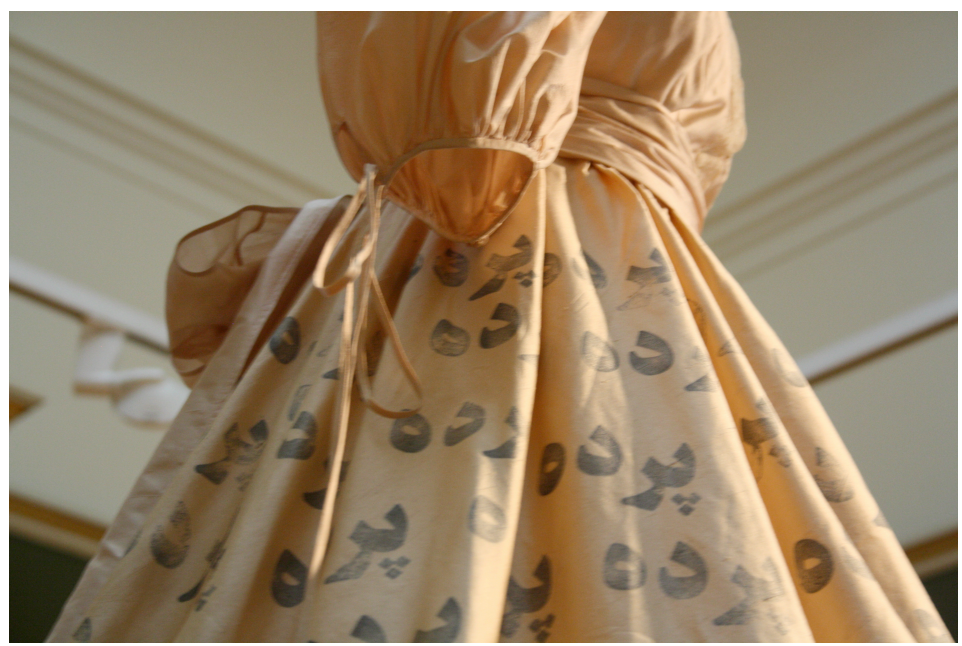

Fig. 2. Pause in Movement, 2012

'In Site' Exhibition, The Ashmolean Museum, Oxford, UK

Site Specific Installation

FZ: What I am trying to do in both these pieces is to explore the concept of dwelling by extending it from its obvious connection with houses and built environments to the more unusual sphere of textiles, and especially female clothing, in various cultures and epochs.

For example: the first piece, Pardeh, was inspired by changes in architectural spaces in Iran during the twentieth century. Prior to this time, courtyard houses were built with extremely visible boundaries (high walls), mainly - although not exclusively - to seclude family life. Significantly, the religious connotations associated with the seclusion of the family are also found in the architecture of the family house. As Nader Ardalan and Laleh Bakhtiar (1973) describe, Iranian residential houses were strongly influenced by sacral buildings, namely by mosques. The usual ground plan of a courtyard house, for instance, is identical to that of an Iranian mosque. Nevertheless, with the increasing cultural influence of Western-style 'modernity' on the traditional society of Iran, the boundaries of 
these houses became more transparent (because new materials, such as glass, were used in their construction) or even invisible (because walls were lowered or destroyed entirely). Consequently, the religious dimensions which were inherent in the courtyard architecture, and which had corresponded to the Islamic notion of sacredness and the concealment of family life, disappeared with the new forms of building and living. Toilets and bathrooms were now located inside the apartment, and balconies opening to the street - an entirely new concept in Iran - disrupted the isolation and confinement which previously had been preserved.

MMF: It is by way of the kinds of issues that you are discussing here, issues/questions of material boundaries, that architectural discourses often raise and interrogate the relations between public and private. These relations, as Thomas Keenan notes, are far from secure: 'For if the window is the opening in the wall constitutive of the distinction between public and private,' he writes, 'it is also the breaching of that distinction itself' (1993: 132). Does the window 'give light,' he asks, or does it 'let the gaze pass through?' (1993: 127). ${ }^{1}$

FZ: Beverley Gordon (1996) makes a similar point, in relation to lace. Gordon has shown how the mass production of lace, its extensive use in interior design and, especially, as curtains at the turn of century in Europe and North America, brought the invisible/private realm of house to the visible/public. The lace curtain, with its translucence and permeability to light, united these two spheres: the outside was in and the inside was out. So too in Pardeh. In Pardeh the word divar, which is Farsi for 'wall', is printed on a curtain which hangs in front of a window. The curtain is purposely thin and transparent in order to evoke the fading away of the word دىوار and, with it, the walled space it represents. In this respect the piece emulates the decline in traditional Iranian domestic architecture and, up until the Iranian revolution in 1979, in traditional Iranian dress code.

MMF: Which brings us to the second piece, which is entitled Pause in Movement (2012). Pause in Movement is a site-specific installation, created for the Ashmolean Museum in Oxford. It is a dress, three metres high, composed of a Victorian bodice from which flows a long golden skirt on which the word pardeh is printed, in Farsi. It stands on a Victorian-style round sofa in the centre of gallery 42 , which displays the Ashmolean's permanent collection of Italian Renaissance paintings of Madonnas. This piece seems to have some kind of relation to pardeh not only in the sense of a curtain, as we have just been discussing, but also in the sense of seclusion (purdah) and veiling, although of course it is notable that the only women who are veiled in this gallery are the Christian Madonnas.

FZ: Yes. The word pardeh, which is printed on the dress, means curtain, but in Farsi it also refers to the 'curtain of virginity' or, to be more precise, it means 'hymen.' In many other Muslim countries the word means veil (with reference to women's clothing) and, although today it is associated with 
Muslim women, its roots are pre-Islamic (El Guindi, 1999). Pardeh has been practiced by numerous women, many of whom are not Muslim, in the course of history. ${ }^{2}$

In Pause in Movement, the multiple meanings of the word pardeh converge. Initially, I was struck by the parallels between the concept of the chador ${ }^{3}$ and the Victorian dress I had designed. Chador can be translated as tent. The dress in Pause in Movement contains the female body like a room or a tent. In the exhibition, some viewers were curious enough to actually lift the rim of the skirt in order to look inside. Like the chador, the skirt in Pause in Movement separates and isolates its wearer from her environment. Potentially, it offers the woman security or, to use Walter Benjamin's words, a 'protective shell' (2010: 126). Why do women (especially) need this? Luce Irigaray proposes that a woman's body is an open envelope, unsealed because of her vagina, which requires another artificial envelope to close it (2004: 12). Clothes - together with other accessories - play exactly that role (Irigaray 2004: 12).

In Pause in Movement I conceptualise the dress/veil as an extended home, an enclosed place for women, a walled space of infinite privacy. Pause in Movement illustrates how the concepts of home, of the private, and of the feminine are separated and constructed not just by materials such as walls and curtains, but also by clothes. I would argue that the dress, the veil, and women's clothing in general, create microcosmic dwelling places.

MMF: These issues - inside and outside, private and public, security and protection (or not) - are also well illustrated in Z. Fareen Parvez's work. Parvez (2011) conducted a very bleak ethnography of a French Salafist women's mosque community in Les Minguettes, which is a poor neighbourhood in a banlieue in Lyon. Although she does not use the words 'microcosmic dwelling places' in her analysis, I think it is possible to understand the struggle that she describes - between these women and the state - in somewhat similar terms.

Parvez argues that, in view of the French state's aggressive interference in the life of its post-colonial subjects - in particular, the surveillance and ultimate closure of many Muslim-identified social spaces - the only response available to these Salafist women is what Parveez describes as an 'anti-politics'. By this, she means that these women use the burqa to create a private sphere and a private practice of the self which they seek to carry into the public domain. This private sphere is not about political, ethical or religious 'resistance'; it is strictly about their relationship with God, and may thus require the expulsion not only of the state, but also of their families.

The French state, however, does not see it like this. The French state claims that wearing the burqa outside the home is sectarian, fundamentalist and promotes violence against women. Parvez's research was carried out before the burqa was banned in France (in April 2011) but this ruling further 
supports her point that, in the eyes of the state, only the women's homes - that is, their architectural dwellings - are considered to be private. By banning the burqa, the state illustrates that it refuses this other form of dwelling, this other form of privacy, in public. As Talal Asad points out, it is the state that 'reserves for itself the final authority' to determine the meaning of 'the religious', and, ultimately, to construct 'the legal distinction between public and private spaces' (2006: 500).

FZ: There are many historical precedents and resonances here. It is worth noting, for instance, that Reza Shah's 4 'modernisation' policies towards women and their dress went hand in hand with continuous attempts - by him and by his son, Mohammad Reza Pahlavi - to diminish the influence of the bazaar right up until the Islamic revolution of 1978-79 (Grigor, 2009: 169). The destruction of parts of Tehran's bazaar and bazaar neighbourhood, which corresponded to the Street Widening act passed by the majles (the Iranian parliament) in November 1933, is just one indication of how concerned the Pahlavis were with these enclosed spaces, which represented the epicentre of the power of the ulama. ${ }^{5}$ Their policies towards women's clothing, and particularly towards the veil another enclosed space and, again, symbol of clerical authority - seems to have been more about gaining a stake in a political power struggle than it was an issue of women's rights. The removal of the veil was made compulsory in 1936. It is no coincidence that while the Iranian women's movement was dissolved in 1933 by Reza Shah (Sanasarian, 1384: 51), and while there was no 'formal' discussion on women's suffrage until 1963, the display of the female body was nevertheless considered an indispensable part of modernity.

MMF: An indispensable part of modernity and, more recently, of 'democracy' and 'freedom' (AbuLughod, 2002; Yegenoglu, 2007). Alain Badiou reminds us that the display of the female body is also indispensible to capital. There is, he claims rhetorically, '[a] single explanation' for the objection to the headscarf in France: 'a girl must show what she's got to sell. She's got to show her goods. She's got to indicate that, henceforth, the circulation of women abides by the generalized model, and not by restricted exchange. Too bad for bearded fathers and elder brothers! Long live the planetary market!' (2004). So what is the generalised model? To my mind it is based, in part, on the idea of a smooth space of global capital over which (some) people and (some) things are 'free' to skate uninterruptedly. Such a space arguably remains the performative ambition of contemporary capitalism, even if its empirical reality, as Mezzadra and Neilson (2008) illustrate, is marked by heterogeneous spaces and times (by proliferations of borders). The generalised model is undoubtedly facilitated by a conception of people and things in terms of 'free-floating' signs, signs unburdened by loyalties, devotions, identities, emotions, disciplines, bodies, practices, affect. Which is precisely how the veil, in most of debates that we have been discussing so far (particularly the debates in France), is conceived: not as a thing of significance in itself, but rather as a 'pointer' to something else/something elsewhere (or even nowhere). The veil as sign could be an expression, for example, of 
religiosity or of religious and/or patriarchal authority. Or it could be a sartorial declaration of Muslim 'identity.'

In his rich and brilliant discussion of French laïcité, ${ }^{6}$ Talal Asad contrasts this understanding of the veil as abstract sign with the veil as religious duty - that is, as an integral part of an ethics of the self. ${ }^{7} \mathrm{He}$ writes:

if the wearer assumes the veil as an obligation of her faith, if her conscience impels her to wear it as an act of piety, the veil becomes for that reason an integral part of herself. For her it is not a sign intended to communicate something but part of an orientation, of a way of being (2006: 501, emphasis in the original).

The difference is politically significant. Consider, for instance, the chain of implications that follows from an understanding of faith in terms of an 'inner' cognitive belief (rather than faith-based practices), as compared to one that foregrounds faith-based practices. In the first place, the marginalisation of faith-based practices renders 'the difference between the man [sic] of faith and one who has no faith virtually unobservable' (Asad, 2001: 140). This unobservability supports, in its turn, 'the modern liberal separation between the public spaces (where our politically responsible life is openly lived) and the private (where one has the right to do with one's own as one pleases)' (Asad, 2001: 140). It is within such a matrix of assumptions - of faith as a private matter which does not require, as a matter of faith, any publicly visible practices, of the veil as 'merely' an expression or sign of an 'interior' belief - that the French state can 'reasonably' demand, by law, that Muslim women remove their headscarves, and can 'reasonably' assume that these women will be able do so without any sense of injury or violation. ${ }^{8}$ And yet for the women in Parvez's study (as we discussed earlier), 'inner' faith and purity of heart is developed through external practices (Parvez, 2011: 304n).

FZ: Indeed. One of the reasons that I bring space-making garments into connection with architecture is because I wish to better apprehend how these garments (built structures) contribute to the construction of subjective experiences and practices - which include, of course, violations. Juhani Pallasmaa highlights the connections between consciousness and built environments when he quotes Kent Bloomer and Charles Moore: 'to at least some extent every place can be remembered, partly because it is unique, but partly because it has affected our bodies and generated enough association to hold it in our personal world' (1996: 28). How does dress as place influence our 'personal world' as women, and how has it affected our behaviour? How conscious are we of dress as place? How has dress been used and exploited in power struggles?

MMF: It seems significant to me that your notion of microcosmic dwelling places enables the often diminished concept of dress - and particularly, within that category, the concept of the veil - to be 
opened up and brought into contact both with other materials (like walls and curtains for example) as well as with material practices. Masserat Amir-Ebrahimi has recently extended her research on traditional women's use of the chador in Iran (2004) to an analysis of religious women's use of the internet (2008). She suggests that, just as compulsory hejab and the segregation of public spaces in Iran enabled traditional or religious women to come out of enclosed physical spaces, out of the interiors of their houses, andarouni, so blogging has made it possible for such women to participate in public life. Her article, which is called 'Blogging from Qom: Behind walls and veils' (2008), brings a further dimension to the original meaning of the word hejab which, in Arabic, refers not to a particular form of dress but to a separation or screen.

FZ: Interestingly, with regards to screens in a most literal sense, the cinema industry was one of many spheres of life in Iran to be affected by the Islamisation of public space, and the universal presence of the hejab system ${ }^{9}$ after the Islamic Revolution. Hamid Naficy argues that the decade after the revolution alone brought forth more women film directors than Iran had seen in the previous eight decades and that this, in its turn, changed the image of women as sexual objects that had dominated the Pahlavi regime. Naficy adds - and this is perhaps relevant to Badiou's point, which you mentioned earlier - that 'although the replacement of this imagery did not give a realistic representation of women's affairs, the complex system of modesty at all levels of the motion picture industry and in the cinematic text, promised to disrupt the direct discursive link between the representation of women and the advertising of corruption, amorality and pornography which the pre-revolution cinema has created' (2003: 138).

MMF: Naficy's work is interesting, I think, insofar as he tries to avoid, as you do, the focus on a single object, for instance 'the veil', in order to explore the organisation of vision and visuality more broadly. '... architecture, dress, behaviour, voice, eye contact and relationships. Walls, words and veils mark, mask, separate and confine ...' (2003: 145). Naficy has argued that hejab in Iran, in its broadest sense (as social rules of modesty), has served to problematize Western cinematic theories, and particularly those in which 'the spectator is made "invisible" through various strategies of mise-en-scène, shot composition and continuity of editing which do not acknowledge the presence of the spectators thus turning them into voyeurs' (2003: 145). The inscription of modesty in Iranian cinema means, by contrast, that 'spectators must be treated as if they were present at the time of filming' (2003: 145). Hejab, in other words, in the Islamic Republic of Iran, makes cinematic modes of visuality, or 'ways of seeing,' visible. And perhaps, in so doing, it burns away the distinction between the light that is needed (according to architectural discourses) for the subject to see out of the window - to see out of the vertical window, the 'humanist window', the window that 'matches and houses the standing, looking, representing figure of the subject' (Keenan, 1993: 126) - and the intense and pitiless 'glare of publicity' that floods the window and 'exposes us to and involves us with others' (Keenan, 1993: 133134). It is this second kind of light, too much light, which maps on to Le Corbusier's horizontal 
window, and which 'tears a hole in [what Benjamin called] "the protective covering of the private person"' (Reichlin in Keenan, 1993: 126, references omitted). You referred to Benjamin earlier Farniyaz, as you were developing the notion of dress/dwelling place as a protective shell. Perhaps, in the Islamic Republic of Iran, all light is considered to be too bright for women, all light brings with it the danger of 'overexposure,' the violence of seeing through and into the dwelling place, rather than 'merely' seeing out of it.

I think your extension of dress to microcosmic dwelling place operates in much the same spirit as Naficy's extension of the concept of hejab. Both enable an exploration of how different modes of visuality - or, more fundamentally, different ways of achieving visibility and/or invisibility (Bal, 2003) serve to organise relations in the social world (between inside and outside, private and public, and so on). A further example of this can be found in your film Puppet behind the Curtain, Puppet behind the Window (2012), which is based on Sadegh Hedayat's short story 'Puppet behind the curtain' (Figures 3 and 4). The role of visuality is especially pronounced in Hedayat's story, and clearly plays a role in organising relations between people (men and women in particular), between people and objects, between people and themselves, and even between life and lifelessness. Could you say a bit about your understanding of 'Puppet behind the curtain' please?

FZ: In Hedayat's short story the main protagonist, a young student abroad, falls in love with a mannequin in a shop-window. The mannequin has all the qualities that the student is looking for in a woman: perfection, serenity, interest. For him, this mannequin 'is not a statue, it is a woman, or even better than a woman ...' (1933: 54). The student consequently buys the mannequin and brings it back to Iran inside - prophetically - a coffin. In order to avoid any conflict with his fiancée, who had been waiting for him during this time, he hides the mannequin behind the curtain in his room and starts a very eccentric love/hate relationship with it. When the fiancée eventually discovers the hidden 'woman' behind the curtain, she becomes jealous and begins to imitate the mannequin's looks and ways. She begins to wear the same clothes, the same make-up, and even carries the same smile on her face. One night, when the man returns home and pulls aside the curtain, 'the statue' walks towards him. In panic, he pulls out his gun and shoots his fiancée.

Both the mannequin and the fiancée in Hedayat's story are somehow perfect. The mannequin is perfect in the way that a model in Vogue magazine would be: she does not exist, she is not real, and she is too remote from real women. This faultless woman is always behind a barrier, whether it is a shop-window or a magazine page. 


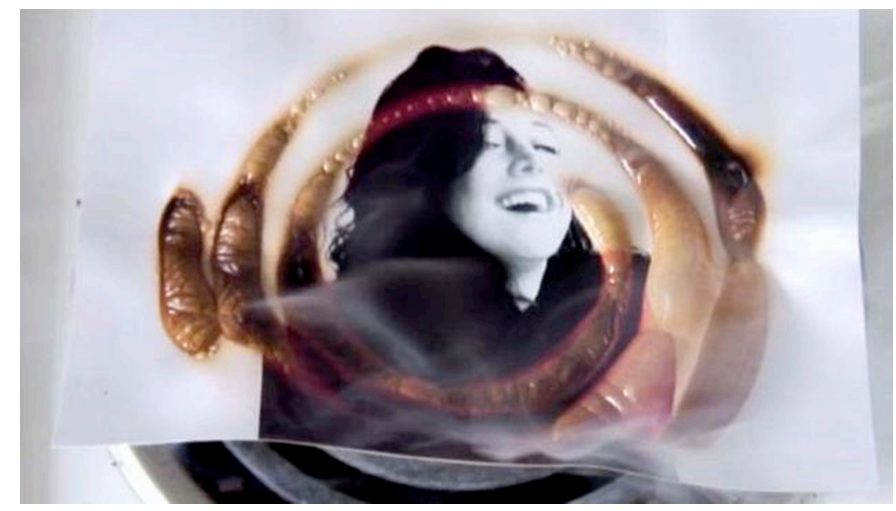

Fig. 3. Puppet behind the Curtain, Puppet behind the Window, 2012

'Rewind Pause, Fast Forward: Mirrors on Iran' Exhibition, Pi Artworks, Istanbul, Turkey Two Channel Short Video Installation

MMF: Rachel Bowlby makes the interesting point that the shop-window is not just a transparent surface through which the observer looks; it is also a reflective surface at which the observer looks. The observer/consumer can see through the shop window (to the mannequin inside) but they are also able, simultaneously, to see themselves reflected in the shop window. Bowlby argues that this combination - of looking through and looking at - is what is significant about the act of 'just looking'. When a woman is 'just looking', she is looking at/looking into/trying on a future reflection of her own self ('if I was wearing that dress ...') (1985: 32). The mannequin in the shop window 'is' what the woman who looks at her could potentially be - or in the case of the Hedayat's story, what she will actually become. The fiancee will turn (herself) into a mannequin.

FZ: It is no coincidence that the first half of the story takes places in Paris, in the land of fashion and 'female flawlessness', where women are promoted as objects of beauty and perfection. The challenges for women in a small Iranian town during the 1930s (where the second half of the story is set) are very different and yet - and this is the point in my film - they are at the same time very similar. In this small town in Iran, conservative values and traditional bonds also treat women as almost statue-like objects. Homa Katouzian describes this woman as the 'embodiment of purity and perfection' (2008: 32). As with the cover-page model, she is a remote and unreal embodiment of an 'ideal' woman. In this case, she is virginal and innocent.

Of course women are not a homogenous group even within a single country. Nevertheless, I sought to draw attention to the shared objectification of women across cultures in Puppet. In my video, I exaggerate to this uncanny resemblance by showing multiple images of both the women (the mannequin and the fiancée). By the end of the video, there are 32 images of a woman (me) veiled and unveiled. My hope is that through this multiplication, we can see that both these women are clones. Cloning is precisely about the relationship between visibility and invisibility. W. J. T. Mitchell 
argues that '... cloning takes the logic of the image as figures of resemblance, similitude and copying to the limit of virulence, toxicity and insidious invisibility' (2008: 184). In my film, every one of the images burns itself up on the rings of an electric hob, just as women are consumed by images of themselves.

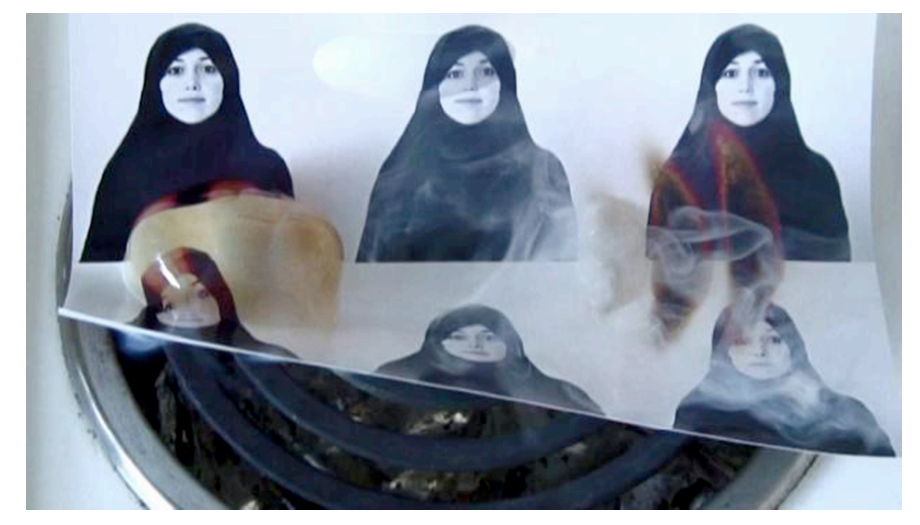

Fig. 4. Puppet behind the Curtain, Puppet behind the Window, 2012

'Rewind Pause, Fast Forward: Mirrors on Iran' Exhibition, Pi Artworks, Istanbul, Turkey Two Channel Short Video Installation.

MMF: There is real violence in both Hedayat's story and in your interpretation of it. All the materials that we have referred to in relation to this story (the window, the magazine page, the curtain) become the mediums through which life is transformed firstly into lifelessness (the woman into a mannequin or clone) and, ultimately, into death. In your video, the ultimate consumption of the women, their burning up into nothing, is foretold by their multiplication or cloning. In the story, the death of the fiancée is tragically foretold when the man carries the mannequin - the object that his fiancée is going to become - home in a coffin. In keeping with our earlier discussions, one could understand the coffin itself to be kind of a microcosmic dwelling-place or enclosure. There are parallels with the figure of Snow White here, lifeless, suspended between life and death, in a glass coffin.

FZ: Somehow we have put Snow White into hejab! In a sense all the aforementioned enclosed spaces are similar to the glass coffin of that fairy tale, which rather brilliantly unites the notion of being both dead and on display.

MMF: Puppet, I think, is something of a bridge between the works we discussed earlier - Pardeh (2011) and Pause in Movement (2012) - and some of your more recent pieces, such as [Ge]Wand II (2013) and a black dress, a red dress (2013). We will talk about both of these in a moment, particularly with regards to the role that words play in them. Firstly though, could you say a bit about your use of words in your work in general? 
FZ: Since 2010, words have become an increasingly integral part of my work. I enjoy playing with, and drawing on the similarities between, text and textiles, to discover the language of textiles. Written texts and woven textiles lend themselves to comparison on many levels, from the linguistic roots that the two words share, ${ }^{10}$ to the structural similarities found in networks of words and threads.

It sounds abstract when I say that I am treating text as textiles, but consider carpets. Carpets, and textiles in a broader sense, are common components of dwellings. I had been printing on carpets earlier in my practice, when I was at Winchester School of Arts, University of Southampton. I studied the techniques, the artistic traditions and cultural/geographical particularities of Persian carpets, which made me more aware both of their aesthetic beauty and of the complexity of the craft and tradition behind them. Not only, for instance, does each pattern tell a story about its origins, but the very process of weaving a carpet (or knitting knit-work, in fact), just as the writing of a text, requires immense concentration and knowledge of elaborate patterns/formulations.

I think of words like the yarn in textiles. In my works, I limit myself to a word or two - sometimes often to only a syllable - something which is similar to the structure of knots in woven textiles. The same knot is repeating itself over and over again until it becomes a meaningful pattern.

MMF: This is evident in one of your most recent pieces, a black dress, a red dress, which was shown at Goldsmiths as part of the Re-Enveloped exhibition (2013) (see Figure 5). a black dress, a red dress was a site-specific piece, made for the Kingsway Corridor. The Kingsway Corridor is a large space, almost a hall, in which two glass cabinets are built into/set level with the walls. You hung a picture of a woman (you), wearing a Victorian-style dress, in each cabinet. Thus, as in your earlier works, the piece seems at least initially to centre on a woman on display. This time, the woman dwells behind layers of glass: behind the glass which frames the pictures, as well as the glass of the cabinets in which the pictures are hung. The cabinet could be a window of a domestic house or a shop, or it could be a glass coffin. You also covered the interior of the cabinets in a floral Victorian-style wallpaper, and you stencilled 'Wand' - which is the German word for wall - on the glass of the cabinet. Finally, while the word 'Wand' appears on the glass, the sound 'Ge' can be heard - just about - through the glass (where you had placed speakers). Taken together, the sound 'Ge' and the written 'Wand' add up to 'Gewand', which is the German word for dress (see also Bruno 2007: 32 on the word Gewand in architecture).

When Althea Greenan, from the Women's Art Library at Goldsmiths, was documenting a black dress, a red dress for the library archive, she proposed that the combination of these materials 'disorientates perspective and troubles the space as the words start to play, or move and merge with the patterns of the wall paper' (personal correspondence). She likened this hallucinatory aspect of the 
piece to Charlotte Perkins Gilman's The Yellow Wallpaper which is very powerfully about the experience of domestic space.

One of the intriguing things for me in this piece is that the borders or boundaries of the word are purposely extended: you have stretched the word Gewand on, over and through the glass screen.

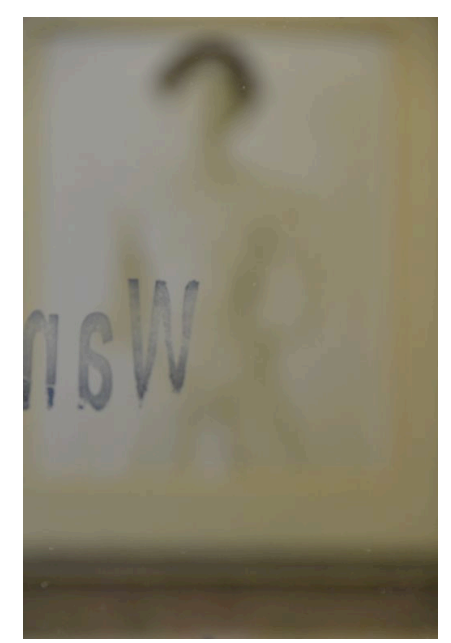

Fig.5. a black dress, a red dress, 2013

'Re-enveloped' Exhibition, Kingsway Corridor, Goldsmiths, London

Site Specific Installation

FZ: I have. And to return to our discussion of texts and textiles: in a black dress, a red dress, the word Wand (wall) is spread over the glass cabinets in a specific pattern which is similar to a particular and uniform knotting technique. The glass window is transformed into a woven textile. The recording of the continuous sound ' $\mathrm{Ge}, \mathrm{Ge} \mathrm{Ge}, \mathrm{Ge}$ ' also relates to the theme of regular knots, of rhythm. On its own, ' $\mathrm{Ge}, \mathrm{Ge}, \mathrm{Ge}$ ' is a meaningless repetitive childish sound, a failed attempt to say something. But it is also an invitation to the audience to 'read' the words across the materials (the glass, the stencilled words, the recorded voice) to discover the 'whole' picture: Gewand (dress).

a black dress, a red dress builds on an earlier piece, called [Ge]Wand II. Although there are no textiles involved in [Ge]Wand II, the syllable 'Ge' runs along all the walls of the gallery, almost like a mantra, weaving them into a single, static Gewand (Figure 6). 


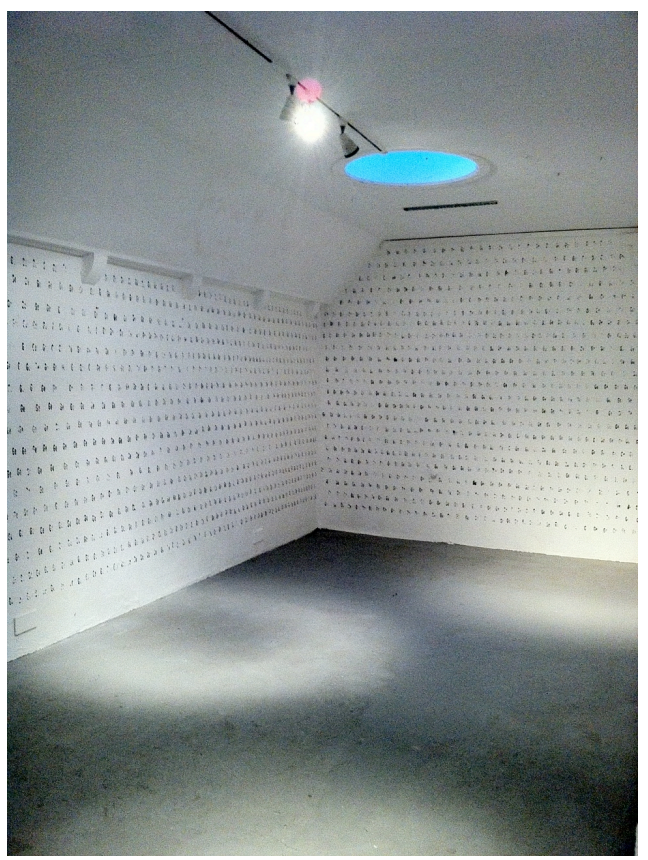

Fig.6. [Ge]Wand II, 2013

'Repeated Return' Exhibition, The Dolphin Gallery, St John's College, Oxford

Site Specific Installation

MMF: In Pardeh and Pause in Movement the audience reads a word on a piece of material. We read the word divar (wall in Farsi) on a curtain and we read the word pardeh (curtain or hymen in Farsi) on a skirt. There is the 'thing' (the curtain and the skirt) and there is the word (divar/wall and pardeh/curtain). The word directs us to think about the thing differently, or more imaginatively - to think of walls in relation to curtains, and curtains and walls in relation to dresses. In this respect you are not following Magritte, who said of his drawing of a pipe that 'This is not a pipe'. It seems to me that what you are saying something more akin to 'this is not just a skirt.' Nevertheless, even though the referent of the word is amplified and extended in Pardeh and Pause in Movement, the way you use words in these earlier pieces remains suggestive of an understanding of words primarily as signs. For it is precisely insofar as the word pardeh refers to more than 'curtain,' it is on account of its very generosity, that it remains locked within a system in which the word refers to something else/something elsewhere. You are proposing ('simply') that it refers to many something elses.

In a black dress, a red dress, you play with the etymological connections between the German words Wand (wall) and Gewand (dress), you stretch the word across different materials and across the visual and the oral, and through the use not only of words, but of words in a particular pattern, in a pattern of uniform repetition, you liken the window - which recalls the shop window and the glass coffin - to a different kind of material entirely: a woven textile. A woven text, in fact. In this piece therefore, in several different ways, words are becoming material. By this I mean that they are not a sign of something or of many things; they are, rather, a part of something. This is also illustrated in 
[Ge]Wand II, in which half of the word (the 'Ge' of Gewand) is recognisable as a written word (that is, as black marks), while the other half (the 'Wand') is a material, it is the wall itself. There are no black marks to stand in for 'Wand'. Instead, the wall itself completes the word that begins ' $\mathrm{Ge}^{\prime}$.

But it is not only words that are material participants in a black dress, a red dress. So too is the body of the observer of the work, for you oblige them to physically engage in the piece by inducing them to press up against the glass (cabinet) in order to hear what is being said. Now, the relation of the audience to the object of representation is no longer marked solely by voyeurism (as we saw Naficy describe the position of the spectator earlier) and, by implication, by distance, but is also one of proximity and tactility. (Which is the difference, as Laura Marks (2000) describes it, between optical and haptic visuality). The audience in a black dress, a red dress must abandon a private or cerebral relation to the text. Reading and looking becomes self-consciously bodily.

This extension of the boundaries of the word, and of the movement of words and parts of words across different materials, recalls Étienne Balibar's observation that, today, borders no longer exist only 'at the edge of territory, marking the point where it ends' but are, rather, 'transported into the middle of political space' (Balibar in Mezzadra and Neilson, 2008). In your work, you show not only that words are borders, borders which require 'work' to cross ('literacy', in a black dress, a red dress, requires the physical participation of all of the observer's body, not just the eyes that look/read), but also that borders are in words. In a black dress, a red dress borders are transported into the middle of words as different materials (the glass, the script, the sound) cut through Ge/Wand. One might say that the veil/veiling too, as both material practice and participant, it is not only 'a sign of ...' but is also configured within a 'border assemblage' that usually includes the state and which defines the boundaries between, for example, public and private, or between 'legitimate' and 'recalcitrant' citizen. Paying attention to borders, accounting for and reacting to them, engaging in the 'multifarious battles and negotiations' that they compel, is part of what Sandro Mezzadra and Brett Neilson describe as 'border as method' (2008). The border, for them, is a way (method) of doing research.

FZ: These are the kinds of questions I am in interested in. In Martin Heidegger's words, visible boundaries are 'not that at which something stops (...)', they are rather 'that from which something begins its presencing' (1971: 154).'

MMF: We have looked, in this article, at some of the ways in which 'microcosmic dwelling places' are made, and at what they are made out of. The materials we have discussed include not only dresses and veils, but also walls, curtains, windows, coffins, and screens. They also, we have argued, include words. Tim Ingold would surely appreciate this, for he argues that, if words have lost their affective capacity, it is in part because they have lost their physical trace. ${ }^{11}$ For Ingold, it is not looking or vision per se, the word as sound-image, that has led to the diminished significance of words 'in themselves'. 
Rather, it is that 'the writer of today is no longer scribe but wordsmith ... the intimate link between the manual gesture and the inscriptive trace is broken' (2007: 3). In a black dress, a red dress however, words are concrete and 'writing' and 'reading' are transformed - or perhaps they are returned (Ingold 2007, chapter five) - to physical practices. 'Recall,' Ingold writes, 'that for readers of medieval times, the text was like a world one inhabits, and the surface of the page like a country in which one finds one's way about, following the letters and words as a traveller follows footsteps or waymarkers in the terrain' (2007: 24). This is only the first step to thinking of words differently; to thinking of them, for example, non-linguistically (Motamedi Fraser 2015).

It is not the materiality of words per se that has been our principal concern here however; our aim, rather, has been to move away from a conception of words solely in terms of abstract signs. The veil is also often perceived to be an especially fecund example of an abstract sign for the very reason, as Farzaneh Milani notes, that it is something of an empty signifier, an abstract 'code' that allows 'anyone and everyone to vent their private aspirations, fears, dreams, and nightmares' (1992: 19). And yet for many women the veil is not a sign at all, but is instead, as we have briefly illustrated, part of a repertoire of devotional practices, or practical modes of living, that have evolved over time in changing historical circumstances. Such practices constitute the pious subject as pious and as such cannot, as Talal Asad elegantly puts it, 'be substituted without loss.' The belief that they can be, Asad writes, exemplifies the essence of the missionary standpoint:

The missionary can't re-form people unless they are persuaded that the formal ways they live their lives are accidental to their being, channels for which other channels can be substituted without loss, enabling conversion from one religion to another, or from living religiously to living secularly (2001: 141).

Asad's analysis indicates that there is much to be gained from insisting that words - and signs more broadly - cannot be understood independently of the texture of physical, material and other practices. By this we mean not only how they are used in practice (for instance, in a particular context) but how they are a part of the bodily, sensual, physical, affective organisation of the subject and the subject in the world.

\section{ACKNOWLEDGEMENTS}

The authors would like to extend warm thanks to the people who put so much energy into making the Re-Enveloped exhibition possible, especially Nirmal Puwar (Methods Lab, Sociology Department, Goldsmiths), Althea Greenan (Women's Art Library, Goldsmiths), and Alan Stanley, without whose patience and technical support the exhibition would not have been realised. Many thanks also to Rebecca Coleman and Yasmin Gunaratnam for their constructive comments on earlier versions. All errors etc are ours. 


\section{AUTHOR BIOGRAPHIES}

Farniyaz Zaker is a multimedia artist. She has been exhibiting her work, world-wide, since 2002. In 2011 she was awarded the Lamb and Flag scholarship from St. John's College Oxford which enabled her to do a PhD in Fine Art at The Ruskin School of Drawing and Fine Arts. Most recently, she has been short-listed for the Arte Laguna Prize 13.14 (Sculpture and Installation Section).

Mariam Motamedi Fraser teaches in the areas of visuality, archives, and the philosophy and methodology of the social sciences in the Sociology department at Goldsmiths, University of London. She is co-Director, with Nirmal Puwar, of the Methods Lab. Her current research interests are in the materiality of words and the feel/experience of different forms of reason. Her book, Word, is forthcoming with Rowman and Littlefield International in 2015.

\section{ENDNOTES}

${ }^{1}$ Keenan illustrates how this 'residual tension in the window ... (gaze out/light in)' also exists in the television screen; specifically, 'in the double incorporation by which television at once contains the world and is then recontained by the home, a home that can then be reintegrated into the world home-system to the extent that "all" the homes share this new inhabitant - the television light' (1993: 130).

${ }^{2}$ MMF: Today, pro-hejab activists in the UK explicitly compare the ideal Muslim woman with the Christian ideal of the Virgin Mary and with nuns' (Tarlo, 2007: 140).

${ }^{3}$ There are many forms of veil in Iran, one of which is the chador, which covers most of the body though not the face.

${ }^{4}$ Reza Shah Pahlavi was the Shah of Iran from 1925 until 1941. He was succeeded by his son, Mohammad Reza Pahlavi, who was overthrown in February 1979 by the Iranian Revolution.

${ }^{5}$ MMF: Reza Shah's architectural, political and sartorial policies also affected - brutally - Iran's southern tribes which were forcibly 'resettled' during the late 1920s and 1930s. Tribal men were very resistant, unsurprisingly, to the Shah's decree, in 1929, that they must wear European suits and the so-called 'Pahlavi caps' (Chehabi, 1993).

${ }^{6}$ Which can be described, most minimally, as French secularism.

${ }^{7}$ There is no reason why these two conceptions should be entirely mutually exclusive. I have represented them, and Asad's view of them, in this way here, however, for strategic and analytic purposes; in particular, to draw stark attention to the political dimensions of the distinction.

${ }^{8}$ For more on the implications of these different ways of understanding the veil - and indeed other 'texts' (including the Qur'an and images of the Prophet Mohammad) - see Motamedi Fraser (forthcoming). 
${ }^{9}$ I use the term 'hejab system' to refer to the organization of behavior, vision, speech, voice etc. - in short, to a system of Islamic modesty that goes beyond any single item of clothing, such as the veil.

${ }^{10}$ The word textile and text derive from the Latin word textus.

\section{LIST OF REFERENCES}

Abu-Lughod, L. (2002) 'Do Muslim Women Really Need Saving? Anthropological reflections on cultural relativism and its others', American Anthropologist 104(3): 783-790.

Amir Ebrahimi, M. (2004) 'Public spaces in enclosure', Pages (February), pps. 3-10.

Amir-Ebrahimi, M. (2008) 'Blogging from Qom, behind Walls and Veils', Comparative Studies of South Asia, African and the Middle East 28(2): 235-249.

Ardalan, N. and Bakhtiar, L. (1973) The Sense of Unity: The Sufi Tradition in Persian Architecture Chicago: Kazi Publications.

Asad, T. (2001) 'Reading a Modern Classic: W. C. Smith's The Meaning and End of Religion', in de Vries, H. and Weber, S. (eds), Religion and Media. Stanford: Stanford University Press. pps. 131-150.

Asad, T. (2006), 'Trying to Understand French Secularism', in de Vries, H, and Sullivan, L. E., (eds), Political Theologies: Public Religions in a Post-Secular World. New York: Fordham University Press. pps. 494-526.

Badiou, A. (2004) 'Behind the scarfed law, there is fear', 22 February, Le Monde.

Bal, M. (2003) 'Visual essentialism and the object of visual culture,' Journal of Visual Culture 2(1): 532.

Benjamin, W. (2001) 'The Arcade Project' in I. Mc Neill (ed.) Memory and Moving Image: French Film in the Digital Era. Edinburgh: Edinburgh University Press.

Bowlby, R. (1985) Just Looking: Consumer Culture in Dreiser, Gissing, and Zola. New York: Methuen.

Chehabi, H. E. (1993) 'Staging the Emporer's New Clothes: Dress Codes and Nation-Building under Reza Shah' Iranian Studies 26(3-4): 209-229.

El Guindi, F. (1999) Veil: Modesty, Privacy, Resistance. Oxford and New York: Berg. 
Gordon, B. (1996) 'Woman's Domestic Body: The Conceptual Conflation of Women and Interiors in the Industrial Age', Winterthur Portfoli: A Journal of American Material Culture 31(4): 281-301.

Grigor, T. (2009) Building Iran. New York: Periscope.

Hedayat, S. (1933) ‘Aroosake Poshte Pardeh’ in Sayeh Roshan. Tehran: Entesharate Javidan. pp. 51-61

Heidegger, M. (1971) Poetry, Language, Thought, translated by A. Hofstadter. New York: Harper \& Row.

Ingold, T. (2007) Lines: A Brief History. London and New York: Routledge.

Irigaray, L. (2004) An Ethics of Sexual Difference, London : Continuum.

Katouzian, H. (2008) Sadeq Hedayat: His Work and His Wondrous World. Abingdon: Routledge.

Keenan, T. (1993) 'Windows: of vulnerability', in Bruce Robbins (ed) The Phantom Public Sphere. London and Minneapolis: University of Minnesota Press. pps 217-234.

Mahmood, S. (2009) 'Religious Reason and Secular Affect: An Incommensurable Divide?', in Asad, T., Brown, W., Butler, J., and Mahmood, S. Is Critique Secular? Blasphemy, Injury, and Free Speech. Berkeley: The Townsend Centre for the Humanities. pps. 64-100.

Marks, L. (2000) The Skin of the Film: Intercultural Cinema, Embodiment and the Senses. London and Durham: Duke University Press.

Mezzadra, S. and Neilson, B. (2008) 'Border as Method, or, the Multiplication of Labor', in transversal, http://eipcp.net/transversal/0608/mezzadraneilson/en.

Milani, F. (1992) 'The concept of the veil', in Veils and Words: The Emerging Voices of Iranian Women Writers. London: I. B. Tauris. pps 19-45

Mitchell, W. J. T. (2008) 'Cloning Terror: The War of Images 2001-04', in D. Costello and D. Willsdon (eds) The Life and Death of Images: Ethics and Aesthetics. London: Tate. pps 179-207. 
Motamedi Fraser, M. (forthcoming) 'Islam in the University: Sociology, Secularity and Practice' (Under review, Sociological Review).

Motamedi Fraser, M. (2015) Word. London: Rowman and Littlefield International.

Naficy, H. (2003) 'Poetics and Politics of Veil, Voice and Vision in Iranian Post-revolutionary Cinema', in Veil: Veiling, Representation and Contemporary Art, A. D. Bailey and G. Tawadros (eds). London: inIVA. pps. 136-159.

Pallasmaa, J. (1996) The Eyes of the Skin: Architecture and Senses. Chichester: Wiley and Sons.

Parvez, Z. F. (2011) 'Debating the burqa in France: the antipolitics of Islamic Revival', Qual Sociol 34: 287-312.

Sanasarian, E. (1384) The Women's Rights Movement in Iran: Mutiny, Appeasement, and Repression from 1900 to Khomeini. Translated to Farsi by N. A. Khorasani. Tehran: Nashre Akhtaran

Tarlo, E. (2007) 'Hijab in London: Metamorphosis, Resonance and Effects', Journal of Material Culture 12(2): 131-156.

Yeğenoğlu, Meyda (2007) 'Clash of secularity and religiosity: the staging of secularism and Islam through the icons of Atatürk and the veil in Turkey', in J. M. Barbalet, A. Possamai, and B. S. Turner (eds) Religion and the State: A Comparative Sociology. London and New York: Anthem Press. 